\title{
ASSESSMENT OF CARBON FOOTPRINTS OF A TYPICAL NIGERIAN TOWNSHIP POST OFFICE: A CASE STUDY OF KAFANCHAN DISTRICT POST OFFICE, KAFANCHAN, NIGERIA
}

\author{
RICHARD BALTHI MSHELIA ${ }^{* 1}$, FUNSHO BABARINDE ${ }^{2}$ \\ ${ }^{1}$ Properties and Workshops Department, Nigerian Postal Service Kafanchan District, \\ Kafanchan, Kaduna State, Nigeria \\ ${ }^{2}$ Department of Mechanical Engineering, Federal Polytechnic Ilaro, Ilaro, Ogun State, \\ Nigeria
}

\begin{abstract}
This research work focuses on carbon footprinting the operations of a township post office in a developing country. The analysis was carried out in accordance with the Universal Postal Union's guidelines for carbon accounting. The results showed that for the inventory year, the office's carbon footprint was 13.3423 tonnes of carbon dioxide equivalent $\left(\mathrm{CO}_{2} \mathrm{e}\right)$. It was found that for each gram of parcel delivered, $0.0171 \mathrm{kgCO}_{2} \mathrm{e}$ was emitted into the atmosphere. Results further showed that $82 \%$ of emission is attributed to delivery of mails while $18 \%$ is as a result of sorting and other minor activities within the facility.
\end{abstract}

Keywords: carbon footprint, global warming, mathematical model, $\mathrm{CO}_{2}$ emission, Nigerian postal service, postal service

\section{INTRODUCTION}

The postal industry is one of the oldest surviving industry in the world, according to the Universal Postal Union (UPU) which is a specialized agency of the United Nations that coordinates postal policies among member nations, the earliest forms of a postal service dates back 2,400 BC in Egypt where there existed a postal service responsible for coordinating the transmission of the emperor's decrees, instructions and other information to the numerous provinces of the empire [1]. The early days of the industry had letters and parcels being couriered on foot and horsebacks, this however changed early in the $20^{\text {th }}$ century when cars began to become a part of our daily lives [2]. The postal industry has had to evolve by adopting modern day technologies that simplify its operations and makes them more efficient.

Increased accessibility to mobile telephoning at the beginning of the $21^{\text {st }}$ century, changing customer demands, competition, unfavorable business divergence and the substitution of paper mail with digital alternatives had led to a decline in the demand for traditional postal services $[3,4]$. This dwindling fortune of the postal industry did not last long as businesses repositioned themselves to take advantage of the pervasive global accessibility of the internet by selling their goods online thus accessing a wider and larger market, this led to the emergence of ecommerce once again breathing life into the postal industry and bringing it more patronage. UPU reports that the ecommerce sector has brought a revenue of about $\$ 320$ billion to the postal industry in the year 2015 [5]. In essence, it can be said that ecommerce has brought about the renaissance of the postal industry. The surge in mail volumes due to ecommerce transactions has increased the need for home delivery of parcels, thus increasing the last mile activity in the postal industry [6], last mile being the phase of final delivery of items to customers.

\footnotetext{
${ }^{*}$ Corresponding author, email: rbmshelia@gmail.com

(C) 2021 Alma Mater Publishing House
} 
Adoption of technology, changes in customers' needs, increasing liberalization of the market and other general changes made in the mode of operations in the industry are responsible for more use of energy in the industry, this consequently has brought about an increase in the carbon footprint of the industry. Globally, the transportation and building sectors are responsible for about $27 \%$ and $34 \%$ of energy use [7], this means that over half of the world's energy consumption comes from the two sectors that the postal industry rely the most for its smooth operations. The tentacles of the postal industry is far reaching, it is reported that approximately $83 \%$ of people globally receive mails and parcels at home [8], this point was further buttressed by the Universal Postal Union when they stated that globally, around 660,000 POs are open to the public, over 700,000 motor vehicles and 250,000 motor cycles travelling hundreds of thousands of kilometres each year delivering mails and parcels, this translates to a high carbon footprint for the industry, in 2009, the postal industry was responsible for the emission of 26 million tonnes of $\mathrm{CO}_{2}[9,10]$.

As efforts to tackle climate change intensify, the business sector being one of the major sources of greenhouse gas (GHG) emissions is not left out in the struggle to keep the increase in global average temperature to well below $2{ }^{\circ} \mathrm{C}$ above pre-industrial levels as resolved in the 2015 Paris Agreement by operating in an eco-friendly and sustainable manner. The postal industry being one with a relatively high carbon footprint is not an exception in this movement for creating sustainable businesses. The first step in the process of reducing the sector's carbon footprint is understanding the emission sources, pattern, and quantity. Kafanchan District PO is one of the 955 POs under the auspices of the Nigerian Postal Service (NIPOST) which is the postal service in Nigeria. NIPOST being a member of UPU is obligated to ply its trade sustainably in line with the UPU's Greenhouse Gas Global Overview and Mitigation Project which is an initiative designed to promote climate conscious operations in the postal sector. The bulk of services provided by Kafanchan PO is the delivery of parcels to customers who have made purchases online and official communication to organizations, essentially, last mile delivery. With the last mile being one of the segments of the postal industry with the highest carbon footprint [11], this research is aimed at assessing the carbon footprint of a typical Nigerian township PO, given that the bulk of services offered by POs in townships are last mile delivery, Kafanchan PO in Kafanchan, Kaduna state of Nigeria is used as a case study. It is expected that potential areas of reduction of GHGs emission from the operations of the PO will be identified and measures to achieve this reduction as suggested by the study will be adopted in accordance with UPU's guideline of reduction in carbon emissions from post offices and in the spirit of operating a sustainable postal service.

\section{MATERIAL AND METHODS}

\subsection{Data sources}

UPU's Greenhouse Gas Global Overview and Mitigation Project sets guidelines to be followed by postal operators when carbon footprinting their operations. These guidelines include how data is to be collected. This research follows guidelines for data collection as outlined by UPU (2009), one calendar year (2019) was used as the inventory year.

For the geographical scope, constants such as fuel emission factors and grid electricity emission for Nigeria were used. While for organizational scope, since Kafanchan PO does not share its buildings or vehicles with others, data for the PO was exclusively used.

There are two major GHGs emission sources related to operations of a PO, these are emissions from processing of parcels and emissions related to delivery of these parcels, that is emission from vehicles and emissions from buildings (electricity usage) [10]. The monthly amount of fuel consumed by each vehicle for the inventory year was collected from the records of the engineering department of the post office. While for electricity usage, the electricity bill for the inventory year was used to extract the data used to estimate the emission from buildings. Records for number and weight of mails delivered each month in the inventory year was also collected from the records of the office's operations unit.

\subsection{Data analysis}

For GHG emissions from the transportation of parcels from the post office to the customers' locations, the emission from each category of vehicle was estimated using the record of fuel consumed for that vehicle together with its emission factor as shown in equation (1) [12]. The vehicle categories involved in delivery of items to customers being motorcycles and vans. 


$$
\text { Emission }\left(\mathrm{kgCO}_{2} \mathrm{e}\right)=\text { fuel used }(\mathrm{L}) \times \text { Fuel Emission Factor }\left(\mathrm{kgCO}_{2} \mathrm{e} / \mathrm{L}\right)
$$

where, Fuel emission factor for gasoline $=2.271 \mathrm{kgCO}_{2} \mathrm{e} / \mathrm{L}[13]$.

The emission from electricity usage was estimated by multiplying the quantity of electricity used in the inventory year with the electricity emission factor as shown in equation (2) [14].

$$
\text { Emission }\left(\mathrm{kgCO}_{2} \mathrm{e}\right)=\text { Electricity used }(\mathrm{kwh}) \times \mathrm{EEF}\left(\mathrm{kgCO}_{2} \mathrm{e} / \mathrm{kWh}\right)
$$

where, EEF = Electricity emission factor. The electricity emission factor for grid electricity in Nigeria being $0.402963 \mathrm{kgCO}_{2} \mathrm{e} / \mathrm{kWh}[10]$.

While for electricity generated from the PO's backup generator, its emission was determined by multiplying the quantity of fuel consumed with the emission factor for stationary gasoline engines as seen in equation (3) [14].

$$
\text { Emission }\left(\mathrm{kgCO}_{2} \mathrm{e}\right)=\text { Quantity of fuel used(L) } \times \mathrm{SEF}\left(\mathrm{kgCO}_{2} \mathrm{e} / L\right)
$$

where $\mathrm{SEF}=$ Stationary Gasoline Engine Emission Factor $=2.286 \mathrm{kgCO}_{2} \mathrm{e} / \mathrm{L}[15]$.

The carbon footprint of each kilogram of parcel processed and delivered at the post office was estimated by dividing the total carbon footprint (from vehicular emissions and electricity usage) of the PO in the inventory year with the total weight of parcels processed at the PO in that inventory as seen in equation (4) [16].

$$
\text { Emission/gram of parcel }=\frac{\text { total emission }\left(\mathrm{kgco}_{2} \mathrm{e}\right)}{\text { total weight of parcels processed and delivered }(\mathrm{g})}
$$

\section{RESULTS AND DISCUSSIONS}

The PO relies on its fleet of 15 motorcycles and one van for delivery of parcels to customers, records of fuel consumption by these vehicles consulted showed that in the inventory year, these vehicles consumed 4,805 liters of gasoline, the 15 motorcycles collectively consumed 3,960 liters of gasoline while the van consumed 845 liters of gasoline.

Using equation (1) and the fuel consumption data obtained, it was obtained that the total footprint from the activities of these vehicles in the inventory year is $10,912.16 \mathrm{kgCO}_{2} \mathrm{e}$. The motorcycles were responsible for $8,993.16 \mathrm{kgCO}_{2} \mathrm{e}$ while the van was responsible for $1,919 \mathrm{kgCO}_{2} \mathrm{e}$ that is $82 \%$ and $18 \%$ respectively.

Noting that emission from delivery of mails was responsible for $82 \%$ of the PO's carbon footprint, it is advised that more efficient methods of delivering parcels should be adopted, this could be proper scheduling [17, 18], or the use of more fuel efficient vehicles $[19,20]$ or even electric motorcycles which have been proven to reduce last mile emission by up to $50 \%[21]$.

Likewise, the post office should consider using tricycles to deliver heavy parcels that cannot be carried by motorcycles since the use of tricycles for delivery have been noted to have a reduction in carbon emissions of about $80 \%$ [21].

To reduce upstream carbon footprint, NIPOST should consider adoption of green postal framework for official communications as suggested by Memon, Uddin \& Rozan [22].

For emissions due to grid electricity usage, electricity bill for the inventory year consulted showed that 4,669 kWh was consumed. Using equation 2, the corresponding carbon footprint from grid electricity usage for the inventory year was estimated to be $1,881.43 \mathrm{kgCO}_{2} \mathrm{e}$. Details of the monthly grid electricity consumption and their corresponding GHGs as estimated is presented in Table 1.

For electricity generated using the PO's backup generator, it was found from records that a total of 240 L of gasoline was used in the inventory year, this information was substituted into equation (3) and it was found that 
$548.69 \mathrm{kgCO}_{2} \mathrm{e}$ was emitted into the atmosphere from onsite generation of electricity. This means that the carbon footprint from the usage of electricity in the PO in a year is $2,430.12 \mathrm{kgCO}_{2} \mathrm{e}$.

Table 1. Grid electricity consumed in Kafanchan PO and corresponding carbon footprint.

\begin{tabular}{|l|c|c|}
\hline Month & Electricity Usage, (kWh) & Emission $(\mathbf{k g C O} \mathbf{C}$ ) \\
\hline January & 604 & 243.39 \\
\hline February & 633 & 255.08 \\
\hline March & 677 & 272.81 \\
\hline April & 508 & 204.71 \\
\hline May & 340 & 137.01 \\
\hline June & 338 & 136.20 \\
\hline July & 267 & 107.59 \\
\hline August & 250 & 100.74 \\
\hline September & 285 & 114.84 \\
\hline October & 277 & 111.62 \\
\hline November & 225 & 90.67 \\
\hline December & 265 & 106.79 \\
\hline Total & $\mathbf{4 , 6 6 9}$ & $\mathbf{1 , 8 8 1 . 4 3}$ \\
\hline
\end{tabular}

Combining the emissions from delivery vehicles with that raked by electricity usage, the total carbon footprint of the PO in the inventory year was estimated to be $13,342.28 \mathrm{kgCO}_{2} \mathrm{e}$. GHGs emission from vehicles having $82 \%$ of the total carbon footprint of the office, while electricity usage being responsible for just $18 \%$. This is not surprising given that the office had gradually replaced all its older electrical equipment and lighting with energy efficient ones in the inventory year hence the gradual decline in electricity consumption rate as noted in Table 1 and a comparatively lower carbon footprint. Figure 1 gives a pictorial representation of the PO's carbon footprint showing all the activities audited and corresponding carbon footprints emission.

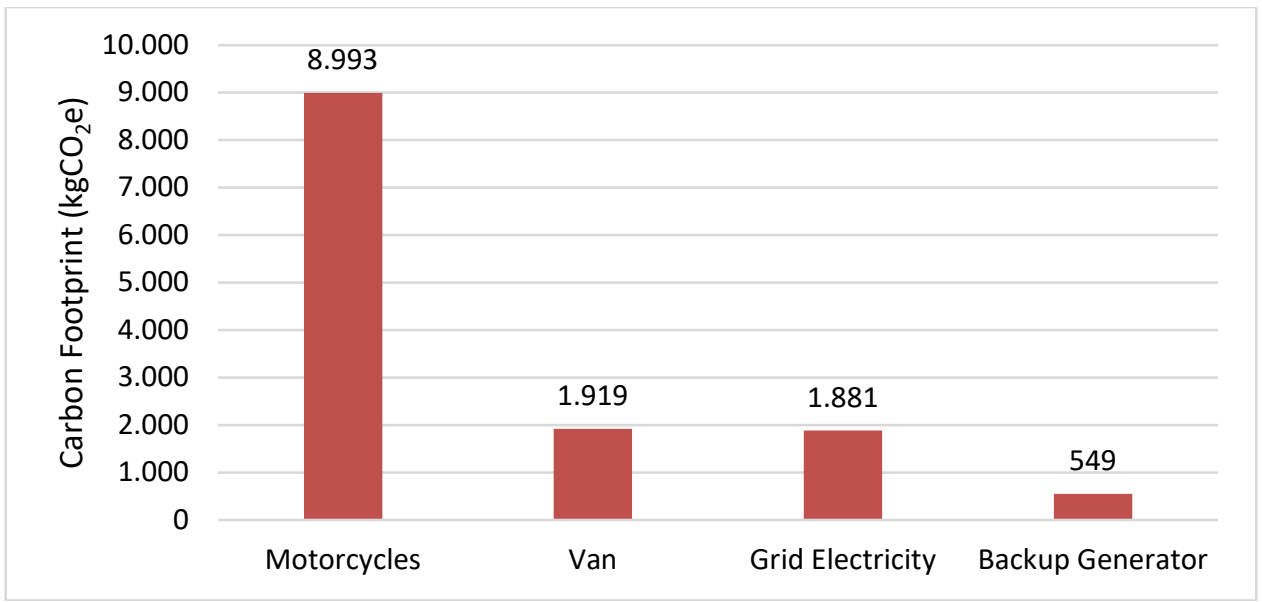

Fig. 1. Summary of activities and their corresponding carbon footprint.

When the total carbon footprint of the post office is compared with those of other POs, it is noted that Kafanchan PO has a relatively low carbon footprint. For instance, a study conducted on Darnall PO in the UK showed the total carbon footprint to be $30.20 \mathrm{tCO}_{2} \mathrm{e}$ [23], this is almost three times that of Kafanchan. Fifty-four percent (54\%) of Darnall PO's carbon footprint was due to transportation while the remaining was emission from the post office building (energy use).

Given that the PO delivered a total of $781.59 \mathrm{~kg}$ of parcels to customers in the year 2019 (Table 2), it was estimated that for each gram of parcel delivered, $0.0171 \mathrm{kgCO}_{2} \mathrm{e}$ was emitted into the atmosphere. 
Table 2. Weight of parcels delivered by Kafanchan PO on a monthly basis in the year 2019 .

\begin{tabular}{|l|c|}
\hline Month & Parcels Delivered (kg) \\
\hline January & 85.40 \\
\hline February & 61.60 \\
\hline March & 60.20 \\
\hline April & 80.94 \\
\hline May & 64.70 \\
\hline June & 40.76 \\
\hline July & 54.70 \\
\hline August & 40.50 \\
\hline September & 65.00 \\
\hline October & 48.00 \\
\hline November & 81.21 \\
\hline December & 98.58 \\
\hline Total & $\mathbf{7 8 1 . 5 9}$ \\
\hline
\end{tabular}

\section{CONCLUSION}

An assessment of the carbon footprint of a typical Nigerian township post office was undertaken using the post office in Kafanchan, Kaduna state as a case study. It was found that in the inventory year, a total of $13,342 \mathrm{kgCO}_{2} \mathrm{e}$ was emitted into the atmosphere from the activities of the PO, of which the last mile delivery of parcels was responsible for about $82 \%$ of that figure while sorting and other related activities at the hub (PO) was responsible for the remaining $18 \%$. Breaking down the emission from the different sectors further, it was found that the PO's 15 delivery motorcycles were responsible for $68 \%$ of its total carbon footprint, while the single delivery van the PO has and backup generator were responsible for $14 \%$ and $4 \%$ of the office's carbon footprint respectively. It was equally found that grid emission from grid electricity was responsible for $14 \%$ of the total carbon footprint.

For emissions from electricity usage, the gradual reduction in the PO's electricity consumption and consequently its carbon footprint can be seen in table 1, this was because of changes implemented in the office's electricity use where old energy consuming equipment were replaced with new energy efficient ones. This could be adopted by other post offices so as to reduce their carbon footprint from electricity usage. In the same vein, going further, NIPOST should prioritise reduction of effective mean temperature when building POs, this will reduce the amount of electricity required for cooling the office space. Furthermore, its energy use footprint can be reduced by supplementing the electricity from the grid with that generated from renewable sources - solar energy in particular since Kaduna is one of the states in Nigeria that enjoys sunlight for about 16 hours daily.

It was equally found that for each gram of parcel delivered, $0.0171 \mathrm{kgCO}_{2} \mathrm{e}$ was emitted into the atmosphere, even though there is no existing benchmark provided by UPU for judging if this figure is high, Kafanchan PO can improve on this.

\section{REFERENCES}

[1] Kielbowicz, R.B., Universal postal service: a policy history, 1790-1970, Post rate communication, 2002.

[2] Leonard, D., Neither snow nor rain: a history of the United States Postal Service, Open Road Grove/Atlantic, 2016.

[3] Pilinkiene, V., Deltuvaite, V., Daunoriene, A., Gaidelys, V., Competitiveness creation and maintenance in the postal services industry, Kaunas, 2016.

[4] Laseinde, O.T., Mpofu, K., Providing solution to last mile challenges in postal operations, Int. J. Logist. Res. Appl., vol. 10, no. 1, 2017, p. 1-16.

[5] UPU, Research on Postal Markets, Geneva, 2016.

[6] Song, L., Guan, W., Cherrett, T., Li, B., Quantifying the Greenhouse gas emissions of local collection and delivery points for last mile deliveries, J. transp. res. board, vol. 2340, 2013, p. 66-73.

[7] WRI, Pivotal Year: 2015 Annual Report, Washington, DC, 2016.

[8] Doherty, J., The Postal Industry: Forging a pathway in green logistics, York University, 2017, p. 170-182.

[9] UPU, The postal sector's primary forum for global cooperation. 2009. [Online]. Available: http://news.upu.int/no_cache/nd/posts-produce-at-least-26-million-tonnes-of-co2-emissions-annually-upus-first- 
global-inventory-reveals/. [Accessed: 10-Jun-2020].

[10] UPU, Greenhouse gas global overview and mitigation project, Geneva, 2009.

[11] Brown, J.R., Guiffrida, A.L., Carbon emissions comparison of last mile delivery versus customer pickup, Int. J. Logistics, no. 10, 2014, p. 37-41.

[12] Bhandari, K., Parida, P., Singh, P., Estimation of carbon footprint of fuel loss due to idling of vehicles at signalised intersection in Delhi, Procedia - Soc. Behav. Sci., vol. 104, 2013, p. 1168-1177.

[13] USEPA, GHG Inventory Guidance, Washington, DC, 2019.

[14] Mshelia, R.B., Diso, I.S., Jibatswen, T.Y., Assessment of greenhouse gases emission sources in a typical Nigerian University campus: case study of Bayero University, Kano new campus, Bayero journal of engineering and technology, vol. 15, no. 2, 2020, p. 30-37.

[15] IPCC, Guidelines for National Greenhouse Gas Inventories. New York: Cambridge University Press, 2006.

[16] PostEurope, GHG Inventory Standard for the Postal Industry, Brussels, 2010.

[17] Bodin, L., Levy, L., Scheduling of local delivery carrier routes for the united states postal service, Arc routing, Springer, 2000, p. 419-442.

[18] Boysen, N., Fedtke, S., Weidinger, F., Truck scheduling in the postal service industry, Including results for transportation Science, vol. 51, no. 2, 2017, p. 723-736.

[19] Trappey, A., Trappey, C., Hsiao, C., Ou, J., Chen, K., An evaluation model for low carbon island policy: The case of Taiwan's green transportation policy, Energy Policy, vol. 45, 2012, p. 510-515.

[20] Bhandari, K., Advani, M., Parida, P., Gangopadhyay, S., Consideration of access and egress trips in carbon footprint estimation of public transport trips: case study of Delhi, Journal of clean production, vol. 85, 2014, p. 234-240.

[21] Saenz-Esteruelas, J., Figliozzi, M., Serrano, A., Faulin, J., Electrifying last-mile deliveries: A carbon footprint comparison between internal combustion engine and electric vehicles, International conference on smart cities, 2016, p. 76-84.

[22] Memon, J., Uddin, M., Rozan, M,A., Green postal service framework to reduce $\mathrm{CO}_{2}$ emissions in postal service industry, International journal of global warming, vol. 5, no. 3, 2013, p. 255-269.

[23] Sophonthammaphat, S., Energy use and carbon footprint at the darnall forum and post office, E-future doctoral training centre, University of Sheffield, Sheffield, 2013. 